\title{
The influence of gut micro-organisms on utilization of dietary protein
}

By D. N. Salter, Nutrition Department, National Institute for Research in Dairying, Shinfield, Reading $R G 29 A T$

In the ruminant the micro-organisms of the digestive tract play an essential role in the nitrogen nutrition of the host animal, but their influence in the protein economy of monogastric animals is certainly less important. However, since many of the reactions involved in the metabolism of proteins may be effected by microorganisms and undoubtedly occur in the gut, it is an interesting question whether they have any measurable effect on the nutrition of the host.

Some of the possible effects of gut micro-organisms on protein digestion are outlined in Fig. I. Incompletely digested protein may come under the influence of bacterial proteases to yield free amino acids, which could be beneficial to the host if they were produced in a region of the gut from which absorption could take place. At the same time, microbial catabolism of amino acids to produce ammonia,

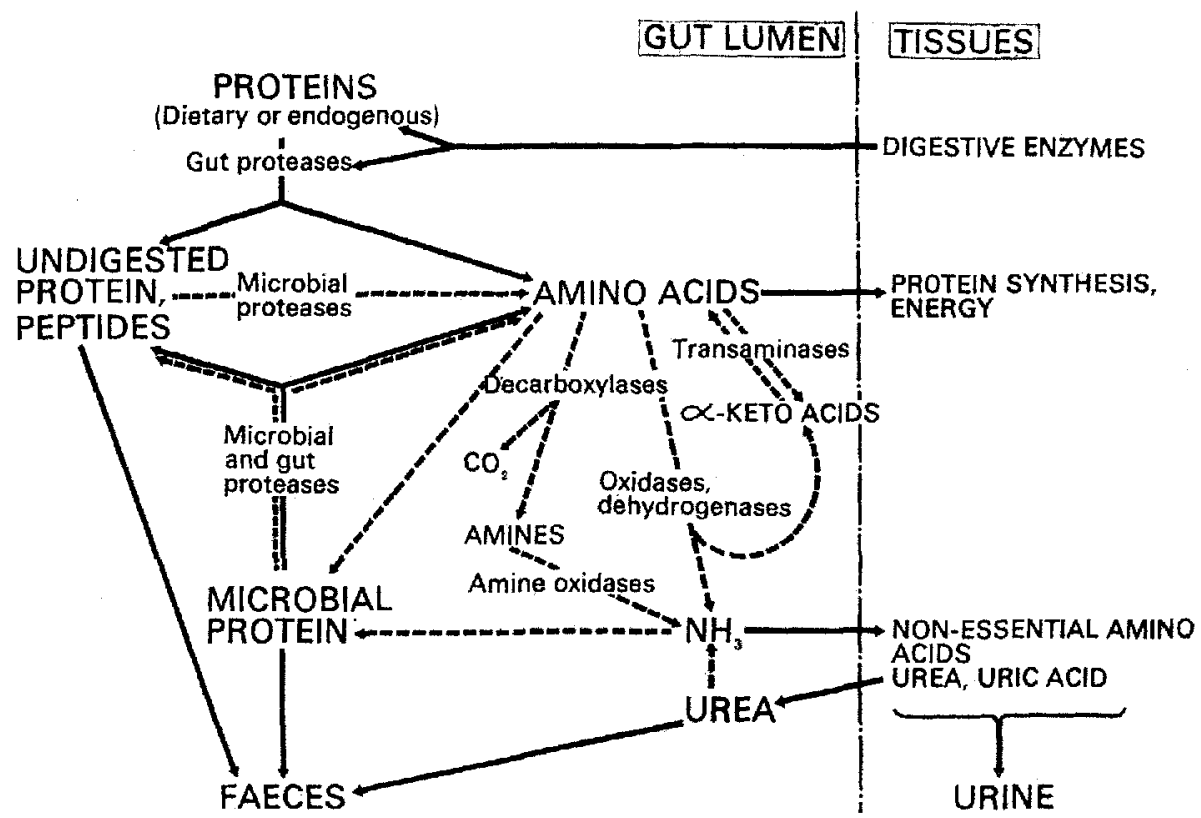

Fig. I. Outline scheme of some possible activities of the micro-organisms of the gut which might influence the course of digestion and utilization of proteins. The broken lines show suggested or known microbial pathways. 
or the incorporation of amino acids into microbial protein, may deprive the host of amino acids. The ammonia produced might be absorbed and utilized in the synthesis of non-essential amino acids, or excreted as such or as urea (or uric acid in birds). Urea, which diffuses into the gut contents from the tissues, may be hydrolysed by bacterial urease to produce further ammonia. All these activities would affect the composition of the digesta and should be reflected in differences between the composition of the gut contents of germ-free (GF) and conventional animals.

\section{The effect of the microflora on the composition of digesta and excreta}

The course of protein digestion in the small intestine of GF and conventional animals is very similar, but differences become apparent in the lower gut where, in the conventional animal, the food residues and endogenous nitrogenous compounds are acted on by the gut microflora. Greatly increased amounts of urea, amino acids, and peptides were found in the caecal contents of GF rats (Combe, Penot, Charlier \& Sacquet, 1965) and chicks (Salter \& Coates, 1970, 1971, and unpublished results), and in GF rats there was also a large increase in the amount of mucoproteins (Lindstedt, Lindstedt \& Gustafsson, 1965). Furthermore, since GF animals contain no bacteria and therefore no urease, their faeces have a higher content of urea. Similar amounts of total $\mathrm{N}$ are excreted by GF and conventional animals (Lindstedt $e t$ al. 1965; Miller, 1967), and the higher faecal $N$ output of GF animals (Levenson \& Tennant, 1963; Evrard, Hoet, Eyssen, Charlier \& Sacquet, 1964) is largely offset by a lower urinary excretion (Reddy, Pleasants \& Wostmann, 1969a).

Mucoproteins and enzymes secreted by the pancreas comprise a high proportion of the endogenous protein $\mathrm{N}$ in the lower gut, and the enlargement of the caecum in the GF rat has been attributed to accumulation of mucoproteins (Lindstedt et al. 1965). Microbial degradation of mucoproteins and inactivation of trypsin and chymotrypsin in the rat caecum have been reported by various workers (Borgström, Dahlqvist, Gustafsson, Lundh \& Malmquist, I959; Lindstedt et al. 1965). Utilization of the products of microbial action on endogenous proteins may have enabled conventional rats to survive starvation longer than GF animals (Loesche, 1968); furthermore the bacteria themselves may be digested in the caecum and the products absorbed (Yang, Bergen, Sculthorpe \& Mickelsen, 1972).

In experiments in which freeze-dried or autoclaved ${ }^{14} \mathrm{C}$-labelled egg white (Salter, Coates \& Westgarth, 1971) was given to GF and conventional chicks (Salter \& Coates, $\left.{ }_{197} \mathrm{r}\right)$, the ${ }^{14} \mathrm{C}: \mathrm{N}$ ratio in samples of digesta taken at different positions along the alimentary tract reflected the balance of ${ }^{14} \mathrm{C}$ uptake and $\mathrm{N}$ secretion and absorption (Fig. 2). In the upper gut no differences were found between GF and conventional chicks, but in the lower gut contents and excreta the ratios were consistently higher in samples from conventional birds. This could have been a consequence of bacterial proteolysis and deamination of amino acids with subsequent absorption of ammonia. This idea was supported by the finding of five times more ammonia in the conventional than in the GF caecal contents and a higher excretion of uric acid by the conventional chicks. These results are also consistent with those of Warren $\&$ 

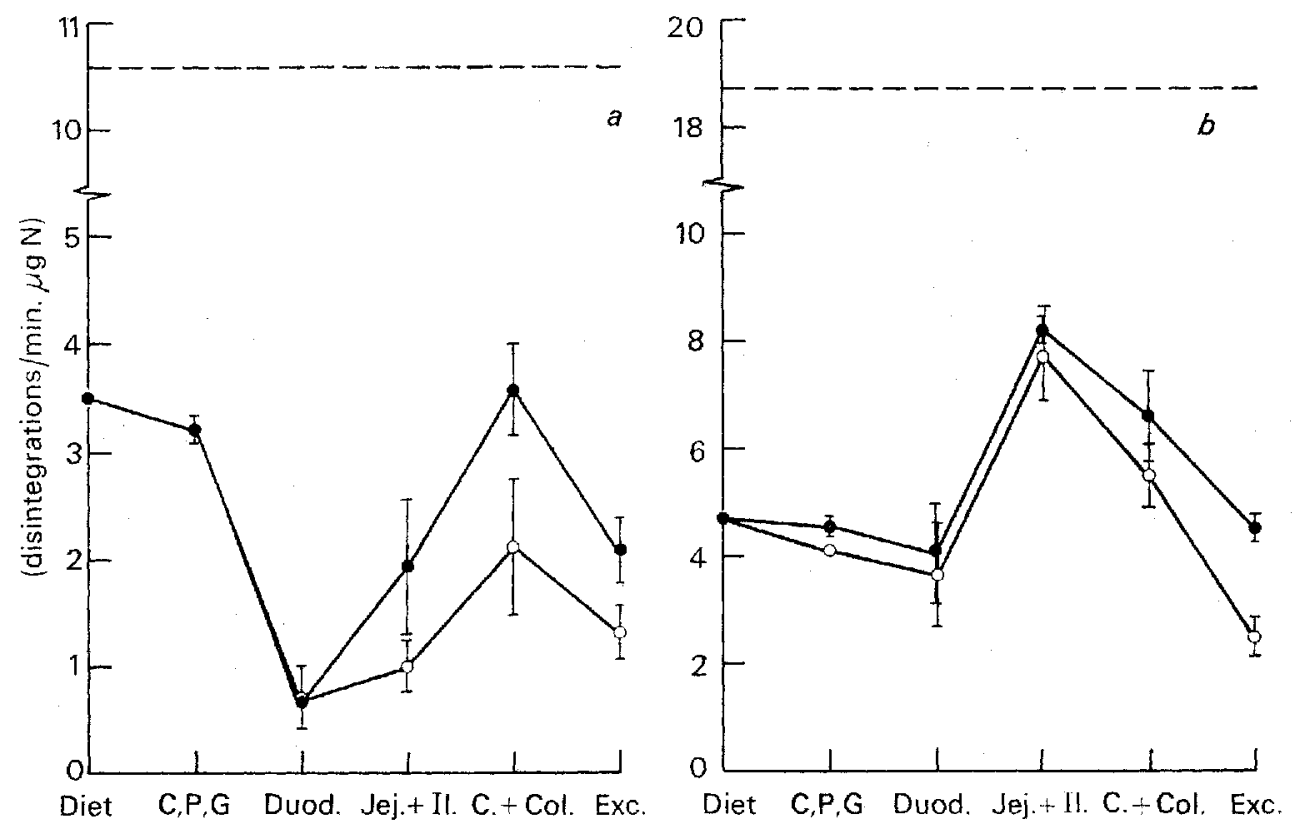

Fig. 2. Ratio ${ }^{14} \mathrm{C}: \mathrm{N}$ in gut contents and excreta of germ-free and conventional chicks given $(a)$, freezedried ${ }^{14} \mathrm{C}$-egg white; $(b)$, heat-damaged ${ }^{14} \mathrm{C}$-egg white. Samples of digesta and excreta were analysed for ${ }^{14} \mathrm{C}$ and $\mathrm{N} 5 \mathrm{~h}$ after giving a single dose of diet containing the labelled protein (Salter $\&$ Coates, r971). $O$, germ-free; $O$, conventional; - - ratio ${ }^{14} \mathrm{C}: \mathrm{N}$ in ${ }^{14} \mathrm{C}$-egg white; $\mathrm{C}, \mathrm{P}, \mathrm{G}$, crop, proventriculus and gizzard; Duod., duodenum; Jej. + I1., jejunum + ileum; C. + Col., caecums + colon; Exc., excreta (less uric acid). The vertical bars represents the standard errors of the mean.

Newton (1959) who demonstrated a fourfold greater concentration of ammonia in the portal blood of conventional than of GF guinea-pigs.

We have also studied uric acid excretion of GF and conventional chicks during $N$ balance trials with a variety of proteins. In general, with heat-damaged proteins and with diets containing a high amount of good quality protein, which may be expected to be incompletely digested and so come under the influence of the microflora in the lower gut, there was more uric acid excreted by conventional chicks than by their GF counterparts (D. N. Salter, unpublished results).

All of these findings indicate that the gut microflora can influence the pathway of $\mathrm{N}$ excretion in the chick, and affect the digestibility of proteins, particularly those of poorer quality. It is possible, however, that if proteins are too severely heatdamaged the micro-organisms are also unable to digest them (Erbersdobler, 1973).

\section{The influence of the microflora on protein utilization}

The indication that the microbial flora influences the pathway of excretion of the residues of protein digestion raises interesting questions concerning its effect on the results of balance methods for the determination of digestibility and biological value. Nesheim \& Carpenter ( 1967 ) pointed out that loss of $N$ from the contents of the lower gut by microbial action would give a spuriously low recovery of faecal $N$, resulting 
in an over-estimate of digestibility, particularly with heat-damaged proteins. Alternatively one could say that the microflora had increased the digestibility of protein. How this would affect measurements of protein utilization would depend on the fate of the $\mathrm{N}$ liberated by the microflora.

Effects on net protein utilization (NPU). NPU is defined as the proportion of the food $\mathrm{N}$ that is retained. This can be expressed in terms of the difference between $\mathrm{N}$ intake and output corrected for endogenous $\mathrm{N}$ excretion:

$$
N P U=\frac{N_{\text {intake }}-\left[\left(N_{F}+N_{U}\right)-\left(N_{F, \text { endogenous }}+N_{U, \text { endogenous }}\right)\right]}{N_{\text {intake }}},
$$

where the subscripts $F$ and $U$ stand for faecal and urinary respectively. The anticipated effect on the recovery of the faecal and urinary $\mathrm{N}$ components and the net result on the NPU value of some of the possible actions of the microflora on dietary protein are shown in Table I. With an abundant dietary supply of amino acids NPU is likely to be the same with GF and conventional chicks, although changes in the amounts of faecal and urinary $\mathrm{N}$ may occur. For example, any amino acids above the requirement that are absorbed must be 'wastefully' metabolized and their $\mathrm{N}$ excreted in the urine. Thus, if the amount of this surplus of amino acids absorbed is

Table I. Possible effects of microflora on nitrogen excretion and net protein utilization (NPU) values ( $N$ balance method)

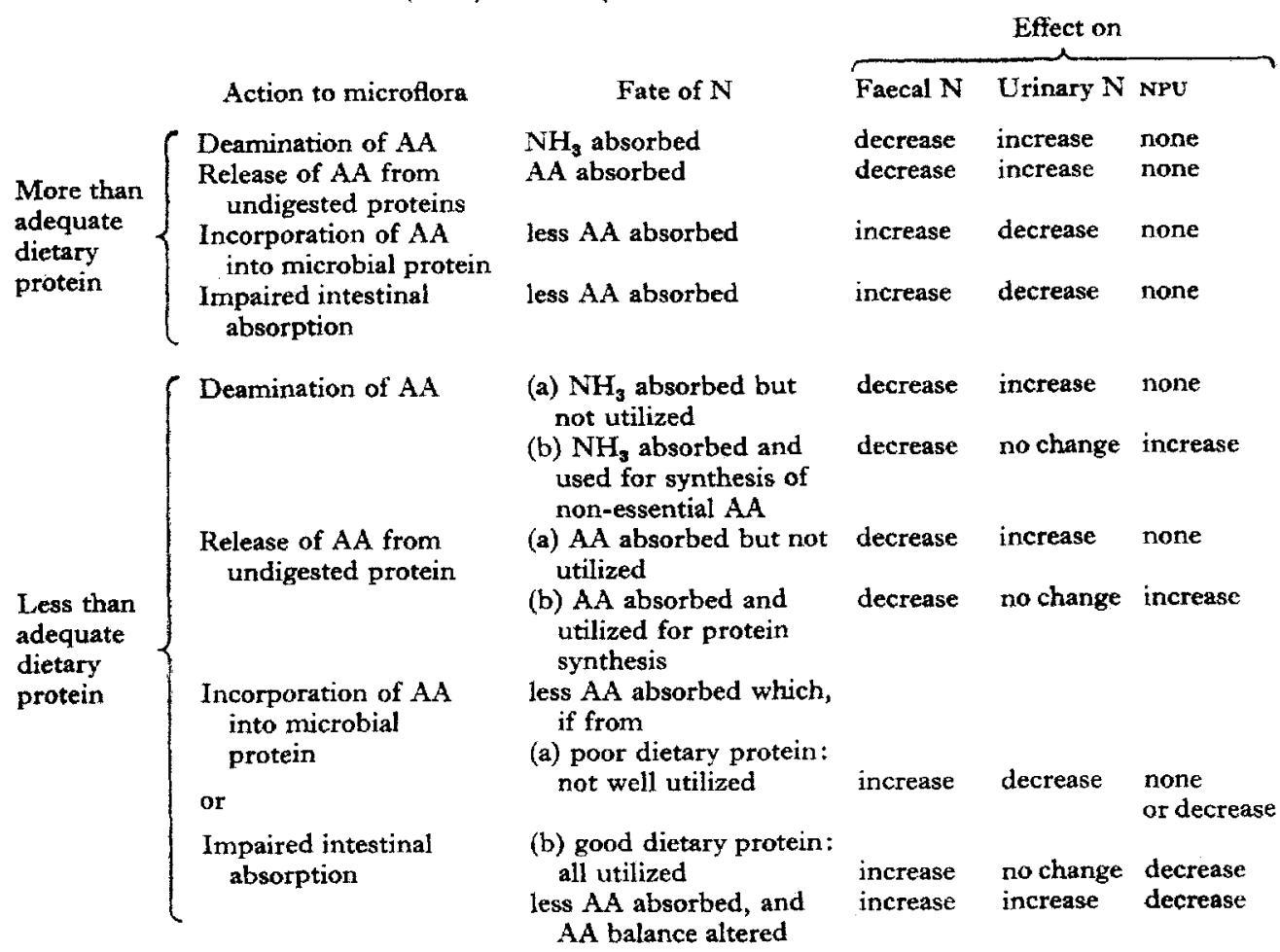

AA, amino acids. 
decreased either by incorporation into microbial protein or by impaired intestinal absorption there will be a corresponding decrease in urinary $\mathrm{N}$ excretion. Substituting the new values for $N_{F}+N_{U}$ in the equation for NPU will therefore produce no change. With a less than adequate dietary supply of amino acids different effects of the microflora could cause either an increase or a decrease in NPU in conventional chicks. We have measured NPU of good- and poor-quality proteins given at relatively high levels in $\mathrm{GF}$ and conventional chicks by N-balance methods (Coates, Hewitt \& Salter, 1973). The results were in keeping with predictions: no differences between results in the two environments were found. It remains to be determined whether an effect of the microflora would be demonstrated with low levels of protein intake. The endogenous $\mathrm{N}$ loss, determined by giving an $\mathrm{N}$-free diet, was higher in the GF chicks $\left(9^{\cdot} 6 \mathrm{~g} / \mathrm{kg}\right.$ food eaten) compared with conventional chicks $(7 \cdot 5 \mathrm{~g} / \mathrm{kg})$, but this difference, although statistically significant, was very small and had no detectable effect on total $\mathrm{N}$ excretion. It may reflect a greater loss of $\mathrm{N}$ from the tissues of the GF birds, or the $\mathrm{N}$ loss from conventional birds was only apparently smaller because of the action of the microflora on endogenous $\mathrm{N}$ residues.

Studies of protein utilization in GF and conventional rats by various workers (Levenson \& Tennant, 1963; Combe et al. 1965; Reddy, Pleasants \& Wostmann, $1969 b)$ have given conflicting results. A systematic study of the effects of protein quality and dietary regimen may resolve these differences.

\section{The gut microflora and $N$ metabolism in man}

$N$ fixation. The extent of the influence of the normal gut microflora on $\mathrm{N}$ metabolism in man has not been fully evaluated. The isolation of cultures of $\mathrm{N}$-fixing bacteria (notably Klebsiella aerogenes) from the intestinal contents of man, pig and guinea-pig (Bergersen \& Hipsley, 1970) led to speculation that N-fixation might occur in the gut and could, under conditions of low $\mathrm{N}$ intake, be nutritionally beneficial. Oomen (1970), in studies of protein metabolism in New Guinean sweet potato eaters with low $\mathrm{N}$ intake, observed that the $\mathrm{N}$ output in the urine and faeces was greater than the $\mathrm{N}$ input from the food. He suggested that $\mathrm{N}$ fixation in the intestines may have been responsible for the presence of surplus $\mathrm{N}$ in the stools.

Excretion of elemental $N$. The converse of this situation has been investigated by others (Costa, 1960; Calloway, Colasito \& Mathews, 1966). In prolonged studies, with successively increasing amounts of $\mathrm{N}$ intake, the body-weights of mice, rats, dogs, pigs, and men failed to increase in proportion to the $\mathrm{N}$ retained, that is above a certain amount of $\mathrm{N}$ intake it was not possible to account for all of the ingested $\mathrm{N}$ by growth and excretion. It was suggested that this could be due to loss of part of the $\mathrm{N}$ as $\mathrm{N}_{2}$, which would have escaped detection in the respiratory gases. Experiments with $\mathrm{GF}$ and conventional mice kept in a closed metabolic system clearly showed an increase in the concentration of $\mathrm{N}$ in the recirculated gases (Costa, Ullich, Kantor $\&$ Holland, 1965,1968$)$. The presence of the gut microflora was not necessary for the production of gaseous $\mathrm{N}$. Similar production of $\mathrm{N}$ was demonstrated with human subjects given a high-protein diet. 
Recycling of $N$. The nutritional potential of recycled $\mathrm{N}$ in man has recently been reviewed by Richards (1972). The microflora of the colon plays an essential part in the reutilization of $\mathrm{N}$ from urea, which is hydrolysed to ammonia by bacterial ureases. This reabsorbed ammonia is available for incorporation into non-essential amino acids necessary for the synthesis of body protein (Foster, Schoenheimer \& Rittenberg, 1939). The proportion of ammonia- $\mathrm{N}$ utilized increases in response to protein restriction (Sprinson \& Rittenberg, I949; Richards, Metcalfe-Gibson, Ward, Wrong \& Houghton, 1967 ). Even with an abundance of recycled N, however, not more than one-third of the total minimum $\mathrm{N}$ requirement was supplied in this way. This is not surprising on theoretical grounds, for the utilization of non-essential amino acids synthesized from ammonia depends on a surplus supply of essential amino acids. Although natural diets supplying adequate intakes of protein may contain an excess of total essential amino acids, it is likely that one or more of these will be in short supply. There is evidence, however, that recycled $\mathrm{N}$ could be used for the synthesis in man of at least three essential amino acids from their corresponding $\alpha$-keto acids when these were supplied in the diet (Richards, Brown, Houghton \& Thompson, 1971; Richards, 1972). Attempts have been made in the treatment of uraemic patients to induce the synthesis of essential and non-essential amino acids from recycled $\mathrm{N}$ by giving the appropriate $\alpha$-keto acids.

\section{Conclusions}

It is now well established that the pattern of $\mathrm{N}$ excretion is modified by the micro-organisms that inhabit the hind-gut, though the extent to which the products of microbial metabolism within the lumen of the gut enter into the $\mathrm{N}$ metabolism of the host doubtless varies widely with species and to some extent also with the diet. With dietary regimens supplying abundant good quality protein, the microflora has only a marginal influence on the protein nutrition of the host. With severely restricted protein intakes and poor quality diets, or in starvation, it is possible that synthesis of non-essential amino acids from $\mathrm{N}$ released as ammonia from urea or poorly digested protein, or recycling of endogenous $\mathrm{N}$, may be of value.

\section{REFERENCES}

Bergersen, F. J. \& Hipsley, E. H. (1970). F. gen. Microbiol. 6o, 6r.

Borgström, B., Dahlqvist, A., Gustafsson, B. E., Lundh, G. \& Malmquist, J. (1959). Proc. Soc. exp. Biol. Med. 102, 154 .

Calloway, D. H., Colasito, D. J. \& Mathews, R. D. (1966). Nature, Lond. 212, 1238.

Coates, M. E., Hewitt, D. \& Salter, D. N. (1973). In Germ-free Research : Biological Effects of Gnotobiotic Environment p.291 [J. B. Heneghan, editor]. New York: Academic Press.

Combe, E., Penot, E., Charlier, H. \& Sacquet, E. (1965). Annls Biol. anim. Biochim. Biophys. 5, i89.

Costa, G. (1960). Nature, Lond. 188, 549.

Costa, G., Ullrich, L., Kantor, F. \& Holland, J. F. (1965). Clin, Res. 13, 320.

Costa, G., Ullrich, L., Kantor, F. \& Holland, J. F. (1968). Nature, Lond. 218, 546.

Erbersdobler, H. (1973). In Proteins in Human Nutrition p. 453 [J. W. G. Porter and B. A. Rolls, editors]. London: Academic Press.

Evrard, E., Hoet, P. P., Eyssen, H., Charlier, H. \& Sacquet, E. (1964). Br. Y. exp. Path. $45,409$.

Foster, G. L., Schoenheimer, R. \& Rittenberg, D. (1939). F. biol. Chem. 127, 3 I 9.

Levenson, S. M. \& Tennant, B. (1 963). Fedn Proc, Fedn Am. Socs exp. Biol. 22, 109.

Lindstedt, G., Lindstedt, S. \& Gustafsson, B. E. (1965). F. exp. Med. r2x, 201. 
Loesche, W. J. (1968). Proc. Soc. exp. Biol. Med, rag, 380.

Miller, W. S. (1967). Proc. Nutr. Soc. 26, x.

Nesheim, M. C. \& Carpenter, K. J. (1967). Br.F. Nutr, 21, 399.

Oomen, H. A. P. C. (1970). Proc. Nutr. Soc. 29, 197.

Reddy, B. S., Pleasants, J. R. \& Wostmann, B. S. (rg6ga). f. Nutr. 97. 327.

Reddy, B. S., Pleasants, J. R. \& Wostmann, B. S. (1969b). Fedn Proc. Fedn Am. Socs exp, Biol, $28,302$. Richards; P. (1972). Am. F. clin. Nutr. 25, 615.

Richards, P., Brown, C. L., Houghton, B. J. \& Thompson, E. (1971), Lancet ii, 128.

Richards, P., Metcalfe-Gibson, A., Ward, E. E., Wrong, O. M. \& Houghton, B. J. (r967). Lancet ii, 845 .

Salter, D. N. \& Coates, M. E. (1970). Proc. int. Congr. Nutr, VIII Prague, 1969, 425.

Salter, D. N. \& Coates, M. E. (I971). Br. J. Nutr. 26, 55.

Salter, D. N., Coates, M. E. \& Westgarth, D. R. (1971). Br. Poult. Sci. 12, 483.

Sprinson, D. B. \& Rittenberg, D. (1949). F. biol. Chem. 180, 707.

Warren, K. S. \& Newton, W. L. (1959). Am. F. Physiol. 197, 717.

Yang, M. G., Bergen, W. G., Sculthorpe, A. E. \& Mickelsen, O. (1972). Proc. Soc, exp. Biol. Med. I39, 1312 . 